\title{
Genetic and epigenetic changes associated with cholangiocarcinoma: From DNA methylation to microRNAs
}

\author{
Monique Stutes, Steven Tran, Sharon DeMorrow
}

\begin{abstract}
Monique Stutes, Sharon DeMorrow, Division of Research and Education Scott and White Hospital, Temple, Texas 76504, United States

Steven Tran, Sharon DeMorrow, Department of Medicine, Texas A\&M Health Science Center, College of Medicine, Temple, Texas 76504, United States

Supported by a NIH mentored award (KO1 DK078532) as well as a grant award from Scott \& White Hospital

Correspondence to: Sharon DeMorrow, PhD, Division of Research and Education, Scott \& White Hospital, Department of Internal Medicine, Texas A\&M Health Science Center, Medical Research Building, 702 SW H.K Dodgen Loop, Temple, TX 76504, United States. demorrow@medicine.tamhsc.edu

Telephone: +1-254-7246240 Fax: +1-254-7248070

Received: August 18, 2007 Revised: September 3, 2007
\end{abstract}

\begin{abstract}
Cholangiocarcinomas are malignant epithelial liver tumors arising from the intra- and extra-hepatic bile ducts. Little is known about the molecular development of this disease, and very few effective treatment options are available. Thus, prognosis is poor. Genetic and epigenetic changes play an integral role in the neoplastic transformation of human cells to their malignant counterparts. This review summarizes some of the more prevalent genetic alterations (by microRNA expression) and epigenetic changes (hypermethylation of specific gene promoters) that are thought to contribute to the carcinogenic process in cholangiocarcinoma.
\end{abstract}

\section{(c) 2007 WJG. All rights reserved.}

Key words: Promoter regions; CDG islands; Tumor suppressor; Oncogene; Inflammation

Stutes M, Tran S, DeMorrow S. Genetic and epigenetic changes associated with cholangiocarcinoma: From DNA methylation to microRNAs. World J Gastroenterol 2007; 13(48): 6465-6469

http://www.wjgnet.com/1007-9327/13/6465.asp

\section{INTRODUCTION}

Neoplastic transformation of normal cells into their malignant counterparts often requires a series of genetic changes. These changes can range from "simple" mutations in the genes themselves that ultimately lead to loss-of-function or gain-of-function changes in key genes that are responsible for the control of apoptosis and cell cycle progression respectively, to more complex changes in non-protein factors (e.g. RNA and DNA) that regulate the control of specific gene expression ${ }^{[1-4]}$. These more complex changes can be classified as either genetic or epigenetic changes ${ }^{[1,3,4]}$. For the purpose of this review, we will define and limit the "complex" genetic changes as being any changes that occur in non-coding RNAs and epigenetic changes in the modification of the promoter regions of the genes themselves (e.g. hyper- and hypomethylation) $)^{[3-6]}$.

\section{Non-coding RNAs}

Non-coding RNAs have recently been recognized as genespecific regulators and therefore are similar in function to transcription factors. These RNAs can regulate every stage of gene expression, including transcription, mRNA stability and translation ${ }^{[5,7]}$. A role for these RNAs in the neoplastic transformation of cells is emerging ${ }^{[4]}$. A major sub-type of non-coding RNA is the microRNAs, which are small RNA molecules encoded in the genomes of plants and animals ${ }^{[5]}$. These highly conserved, about $21-$ mer RNAs regulate the expression of specific target genes by binding to the 3 '-untranslated regions of mRNAs ${ }^{[7]}$. Each microRNA is thought to regulate multiple genes and since hundreds of microRNA molecules are predicted ${ }^{[6]}$, the relative importance of these molecules in the control of gene expression is potentially massive. Several research groups have provided evidence that microRNAs may act as key regulators of processes as diverse as early development ${ }^{[8]}$, cell proliferation and cell death ${ }^{[9]}$, apoptosis and fat metabolism ${ }^{[10]}$, and cell differentiation ${ }^{[11,12]}$. In addition, recent studies suggest a possible link between microRNAs and various cancers, including chronic lymphocytic leukemia ${ }^{[13]}$, colonic adenocarcinoma $a^{[14]}$, Burkitt's Lymphoma ${ }^{[15]}$ and cholangiocarcinoma ${ }^{[16-18]}$.

\section{Epigenetic changes}

Epigenetic gene silencing refers to non-mutational gene inactivation that can be passed from parental cells to daughter cells ${ }^{[1]}$. The addition of methyl groups to cytosine residues in CPG dinucleotides in DNA is a biochemical modification that meets this requirement, referred to as hypermethylation ${ }^{[1]}$. Genes carrying epimutations 
cause morphological phenotypes to be transmitted from generation to generation, not based on any alteration in the coding sequence of the relevant genes, but instead caused by $\mathrm{CpG}$ (or $\mathrm{CpNpG}$ ) hypermethylation of their promoter sequences ${ }^{[2]}$. Methylation patterns in mammalian cells are regulated by DNA methyltransferases ${ }^{[19]}$, which transfer a methyl group to the cytosine portion of the CpG dinucleotide ${ }^{[19]}$. This allows for the binding of methyl-specific DNA-binding proteins such as MeCP1 or $\mathrm{MeCP} 2$ to regulatory elements, which in turn represses transcription ${ }^{[20]}$. These binding proteins can then attract histone deacetylases, which then remodel chromatin into highly repressed states ${ }^{[20]}$. Hypermethylation has been shown to play an important role in the progression of tumor growth in almost all types of cancer ${ }^{[21]}$.

Recent data suggest that both genetic and epigenetic changes are required for transformation, promotion and progression of cholangiocarcinoma ${ }^{[16,17,22-26]}$, a deadly cancer of the cells lining the intra- and extra-hepatic biliary tract ${ }^{[27,28]}$. This type of cancer is increasing in its incidence worldwide, with no effective treatment options ${ }^{[29,30]}$. Therefore, understanding the molecular events associated with the neoplastic transformation of cholangiocytes to cholangiocarcinoma may aid in the development of improved therapeutic strategies. This review will summarize our current understanding of the most prevalent genetic and epigenetic changes associated with cholangiocarcinoma.

\section{THE REGULATION OF TUMOR SUPPRESSOR GENES AND CELL CYCLE INHIBITORS}

\section{Methylation}

The hypermethylation and inactivation of a number of cell cycle inhibitors have been shown to occur in cholangiocarcinomas. The most well-characterized of these epigenetic changes is in the $\mathrm{p} 16^{\mathrm{INK} 4 \mathrm{a}}$ gene, which has been described in up to $83 \%$ of cholangiocarcinomas ${ }^{[23,26]}$. This gene is responsible for binding to the cyclin dependent kinase 4 (CDK4) and inhibits its ability to interact with cyclin D $1^{[31]}$. In the absence of $\mathrm{p} 16^{\text {INK4a }}$ activity, such as after promoter methylation, CDK4 binds to cyclin D1, which subsequently leads to unchecked entry into the $\mathrm{S}$ phase of the cell cycle ${ }^{[31]}$. There also appears to be increased incidence of hypermethylation of the related $\mathrm{p} 14^{\mathrm{ARF}}$ occurring in $25 \%$ of cholangiocarcinoma samples studied ${ }^{[25]}$. The $\mathrm{p} 14^{\mathrm{ARF}}$ gene normally prevents p53 degradation and hence cell-cycle arrest ${ }^{[32]}$, which constitutes another checkpoint that may be lost in cholangiocarcinoma $^{[33]}$. In addition to the above-mentioned genes, many other cell cycle entry inhibitors have been shown to be hypermethylated. These include $\mathrm{p} 16^{\mathrm{INK} 4 \mathrm{~b}}(50 \%$ of tumors studied $)^{[26]}$ and $14-3-3$ sigma $(59.5 \%$ of tumors studied) ${ }^{[34]}$.

In addition, the expression of many tumor suppressor genes is repressed in cholangiocarcinomas ${ }^{[2]}$. The most striking of which is Semaphorin3B, which was found to be methylated in $100 \%$ of the cholangiocarcinoma cases studied ${ }^{[24]}$. RassF1 $\mathrm{A}^{[26]}$ and $\mathrm{p} 73^{[26]}$ are also hypermethylated and suppressed in $65.3 \%$ and $36.1 \%$ of cholangiocarcinoma cases studied respectively.

Taken together, the epigenetic silencing of a vast array of tumor suppressor genes and inhibitors of cell cycle progression obviously plays an important role in the initiation and progression of cholangiocarcinoma. Inactivation of these genes allows cells to avoid apoptosis and to proliferate unchecked.

\section{microRNA}

To date, the data concerning microRNA regulation of cell cycle and/or apoptotic genes is sparse. Recently Meng et al showed that miR-141 was highly overexpressed in malignant cholangiocytes ${ }^{[16]}$. Using a bioinformatics approach, a predicted target of miR-141 was the CLOCK gene, which regulates circadian rhythms and can act as a tumor suppressor ${ }^{[16]}$. Inhibiting miR-141 effectively increased CLOCK protein expression in cholangiocarcinoma cells ${ }^{[16]}$. Another microRNA species that was found to be overexpressed in malignant cholangiocytes was miR-200b ${ }^{[16]}$. The target gene for this was predicted to be the protein tyrosine phosphatase nonreceptor type 12 (PTPN12), the dysregulation of which may contribute to tumor cell survival and oncogenesis ${ }^{[16]}$. Similarly, the expression of miR-21 was overexpressed in cholangiocarcinoma, which effectively blocks the expression of the tumor suppressor gene PTEN ${ }^{[16]}$.

Conversely, other microRNA species have been identified as being downregulated in cholangiocarcinoma compared to non-malignant cholangiocytes. miR-29b expression was suppressed in the cholangiocarcinoma cell line $\mathrm{KMCH}$ as well as in approximately 33\% of human cholangiocarcinoma samples ${ }^{[18]}$. Enforced miR$29 b$ overexpression in cholangiocarcinoma cells effectively reduced the expression of $\mathrm{Mcl}-1$, an anti-apoptotic protein of the Bcl-2 family ${ }^{[18]}$ and sensitized cholangiocarcinoma cells to tumor necrosis factor-related apoptosis-inducing ligand cytotoxicity, suggesting that the suppression of miR-29b expression found in cholangiocarcinoma allows the overexpression of $\mathrm{Mcl}-1$ and can ultimately lead to the resistance of cholangiocarcinoma to cell death ${ }^{[18]}$. Another microRNA that is downregulated in cholangiocarcinoma is miR-370 ${ }^{[17]}$. Interestingly, the expression of this particular microRNA has been shown to be under tight epigenetic regulation by hypermethylation ${ }^{[17]}$. One of the targets for miR-370 is the oncogene mitogen-activated protein kinase kinase kinase 8 (MAP3K8) ${ }^{[17]}$, thus MAP3K8 is upregulated in cholangiocarcinoma cell lines as well as in tumor cell xenografts in vivo ${ }^{[17]}$.

\section{THE REGULATION OF GENES INVOLVED IN DNA REPAIR}

\section{Methylation}

Inherited mutations that affect DNA repair genes are strongly associated with high cancer risks in humans. A number of the DNA repair genes have been shown to be hypermethylated in cholangiocarcinoma. Hypermethylation of the hMLH1 mismatch repair gene promoter has been shown to occur in up to $23.6 \%$ 
of cholangiocarcinomas ${ }^{[26]}$, which has previously been revealed to lead to microsatellite instability in other tumor types ${ }^{[35]}$. Another gene, O6-methylguanine-DNA methyltransferase (MGMT), is silenced in up to $33 \%$ of cholangiocarcinoma tumors studied ${ }^{[26]}$. This gene is an important suicide enzyme involved in the defense against O6-alkylating endogenous metabolites and environmental carcinogens. Interestingly, transcriptional repression of MGMT was associated with the accumulation of GCAT transitional mutations in the p53 gene and, to a lesser extent, the k-ras gene in cholangiocarcinoma ${ }^{[26,36]}$. Lastly, the glutathione S-transferase P1 (GSTP1) gene, which inactivates electrophilic carcinogens by conjugation with glutathione is hypermethylated in cholangiocarcinoma, occurring in $6 \%$ to $34 \%$ of cases studied ${ }^{[26,34]}$. Taken together, the hypermethylation of genes responsible for DNA repair appears to be an important step in the carcinogenic process of cholangiocarcinoma.

\section{microRNA}

To our knowledge, and to date, no genes involved in DNA repair have been identified as targets of transcriptional control by microRNA in cholangiocarcinoma.

\section{THE REGULATION OF GENES INVOLVED IN INFLAMMATION}

\section{Methylation}

Chronic inflammation, such as those seen in various cholestatic liver diseases, is a recognized risk factor for the development of cholangiocarcinoma ${ }^{[27,28]}$. Therefore, it follows that certain mediators of the inflammatory process may be integral in the carcinogenic processes associated with neoplastic transformation of cholangiocytes ${ }^{[37-39]}$. Indeed, sustained overexpression of the cytokine interleukin- 6 (IL-6) has been demonstrated to have an integral role in cholangiocarcinoma biology ${ }^{[38,39]}$. This aberrant overexpression of IL-6 has recently been shown to be as a consequence of the epigenetic silencing of the suppressor of cytokine signaling 3 (SOCS-3) ${ }^{[40]}$. SOCS-3 promoter methylation was observed in a subset of cholangiocarcinoma samples as well as in a number cholangiocarcinoma cell lines ${ }^{400}$. Enforced overexpression of SOCS-3 in these cell lines effectively reduced the IL-6mediated signal transduction cascade ${ }^{[40]}$. Therefore the loss of this negative regulator of IL-6 in cholangiocarcinoma may contribute to the inflated expression and activity of inflammatory molecules seen in cholangiocarcinoma.

A downstream consequence of aberrant IL- 6 expression may be the further hypermethylation of the promoter regions of a number of critical target genes in cholangiocarcinoma. IL-6 has been shown to regulate the enzyme activity of one of the DNA methyltransferases responsible for the hypermethylation of promoter regions ${ }^{[41]}$. In cholangiocarcinoma cells, IL-6 overexpression resulted in the altered promoter methylation of a number of genes including the epidermal growth factor receptor (EGFR) ${ }^{[42]}$. EGFR promoter methylation was decreased and gene and protein expression increased by IL- $6^{[42]}$, suggesting that the epigenetic regulation of gene expression by the inflated IL-6 expression seen in cholangiocarcinoma can contribute to tumor progression by altering the expression of growth regulatory pathways, such as those involving EGFR ${ }^{[4]}$.

\section{microRNA}

In addition to changes in promoter methylation, aberrant IL-6 expression in cholangiocarcinoma also has implications on microRNA expression and function. Enforced IL- 6 overexpression in human cholangiocarcinoma cell lines significantly increased the expression of several members of the let- 7 family of microRNAs ${ }^{[22]}$. Expression of let- 7 a contributes to the survival effects that are attributed to IL- 6 overexpression ${ }^{[22]}$. A putative target of let-7a microRNA is the gene neurofibromatosis $2(\mathrm{NF} 2)^{[2]}$, which is a negative regulator of Stat- $3^{[43]}$. Thus, overexpression of IL-6 in cholangiocarcinoma and subsequent upregulation of let7a decreased the expression of NF2, thereby removing the negative regulation of Stat- $3^{[2]}$. Constitutive activation of Stat- 3 has been implicated in a number of cancers and is thought to be responsible for the IL-6-mediated survival signaling ${ }^{[22]}$.

\section{THE REGULATION OF GENES INVOLVED IN CELL ADHESION AND INVASION}

\section{Methylation}

E-Cadherin is a calcium-dependent cell adhesion molecule that suppresses metastatic processes and tumor cell invasion ${ }^{[4-46]}$. In cholangiocarcinoma, methylation of the E-cadherin promoter occurred in up to $48 \%$ of all samples studied ${ }^{[25,26,34,4]}$. Downregulation of this gene by epigenetic changes has been reported in a number of other cancers $^{[4,45]}$, and re-expression can be induced by treatment with a demethylating agent in cholangiocarcinoma ${ }^{[48]}$.

\section{microRNA}

To our knowledge, no genes that are involved in cell adhesion or the metastatic process associated with cholangiocarcinoma biology have been shown to be regulated by microRNAs.

\section{CONCLUSION}

In conclusion, from the epigenetic changes summarized in this review, it is obvious that epigenetic silencing as well as genetic regulation by microRNAs play a very important role in the neoplastic transformation of cholangiocytes to their malignant counterparts. A summary of the changes in specific promoter hypermethylation and microRNA can be found in Tables 1 and 2 respectively. We acknowledge that this summary is far from complete and that more target genes are being described regularly. Further analysis and characterization of these genetic and epigenetic changes, as well as the potential interplay between hypermethylation and microRNA expression will aid in the identification of therapeutic targets for the design of treatment strategies to combat this deadly malignancy. 
Table 1 Summary of genes subject to epigenetic silencing during the course of cholangiocarcinoma tumor progression

\begin{tabular}{|c|c|c|c|}
\hline Gene & $\begin{array}{l}\text { Incidence of } \\
\text { methylation in } \\
\mathrm{CCH}(\%)\end{array}$ & Function & Reference \\
\hline $\mathrm{p} 16^{\mathrm{INK} 4 \mathrm{a}}$ & $14-50$ & Cell cycle regulator & {$[26,34,47]$} \\
\hline $\mathrm{p} 14^{\mathrm{ARF}}$ & 38 & Cell cycle regulator & [26] \\
\hline $\mathrm{p} 15^{\mathrm{INK} 4 \mathrm{~b}}$ & $12-50$ & Cell cycle regulator & {$[26,47]$} \\
\hline 14-3-3 sigma & 59.50 & Cell cycle regulator & [34] \\
\hline Semaphorin3B & 100 & Tumor suppressor & [24] \\
\hline p73 & 36 & Tumor suppressor & {$[26]$} \\
\hline RassF1A & $26-65$ & Tumor suppressor & {$[26,47]$} \\
\hline hMLH1 & 25 & DNA mismatch repair & [26] \\
\hline MGMT & $11-33$ & Methyl transferase & {$[26,34]$} \\
\hline GSTP1 & $6-34$ & Inactivation of carcinogens & {$[26,34]$} \\
\hline SOCS-3 & ND & Inhibits inflammation & {$[40]$} \\
\hline EGFR & ND & Growth factor & {$[42]$} \\
\hline E-cadherin & 43 & Cell adhesion & {$[25,26,34,47]$} \\
\hline
\end{tabular}

ND: Not determined

Table 2 MicroRNAs known to be changed in cholangiocarcinoma

\begin{tabular}{|c|c|c|c|c|}
\hline MicroRNA & $\begin{array}{l}\text { Target } \\
\text { gene }\end{array}$ & Function & $\begin{array}{l}\text { Direction } \\
\text { changed } \\
\text { in } \mathrm{CCH}\end{array}$ & Reference \\
\hline miR-141 & CLOCK & Circadian rhythm & Increased & {$[16]$} \\
\hline miR-200b & PTPN12 & Tumor suppressor & Increased & {$[16]$} \\
\hline miR-21 & PTEN & Tumor suppressor & Increased & {$[16]$} \\
\hline miR-29b & Mcl-1 & Anti-apoptotic gene & Decreased & [18] \\
\hline miR-370 & MAР3К8 & Oncogene & Decreased & [17] \\
\hline let-7a & NF2 & $\begin{array}{l}\text { Negative regulator } \\
\text { of inflammation }\end{array}$ & Increased & [22] \\
\hline
\end{tabular}

\section{ACKNOWLEDGMENTS}

We thank Meg Chrisler, Medical Editor of Scientific Publications, Research and Education Department, Scott and White Memorial Hospital, for proofreading this manuscript.

\section{REFERENCES}

1 Karpf AR. Epigenomic reactivation screening to identify genes silenced by DNA hypermethylation in human cancer. Curr Opin Mol Ther 2007; 9: 231-241

2 Nelson WG, Yegnasubramanian S, Agoston AT, Bastian PJ, Lee BH, Nakayama M, De Marzo AM. Abnormal DNA methylation, epigenetics, and prostate cancer. Front Biosci 2007; 12: 4254-4266

3 Dalmay T, Edwards DR. MicroRNAs and the hallmarks of cancer. Oncogene 2006; 25: 6170-6175

4 Kent OA, Mendell JT. A small piece in the cancer puzzle: microRNAs as tumor suppressors and oncogenes. Oncogene 2006; 25: 6188-6196

5 Pillai RS. MicroRNA function: multiple mechanisms for a tiny RNA? RNA 2005; 11: 1753-1761

6 Lim LP, Glasner ME, Yekta S, Burge CB, Bartel DP. Vertebrate microRNA genes. Science 2003; 299: 1540

7 Valencia-Sanchez MA, Liu J, Hannon GJ, Parker R. Control of translation and mRNA degradation by miRNAs and siRNAs. Genes Dev 2006; 20: 515-524

8 Reinhart BJ, Slack FJ, Basson M, Pasquinelli AE, Bettinger JC, Rougvie AE, Horvitz HR, Ruvkun G. The 21-nucleotide let-7 RNA regulates developmental timing in Caenorhabditis elegans. Nature 2000; 403: 901-906

9 Brennecke J, Hipfner DR, Stark A, Russell RB, Cohen SM. bantam encodes a developmentally regulated microRNA that controls cell proliferation and regulates the proapoptotic gene hid in Drosophila. Cell 2003; 113: 25-36

10 Xu P, Vernooy SY, Guo M, Hay BA. The Drosophila microRNA Mir-14 suppresses cell death and is required for normal fat metabolism. Curr Biol 2003; 13: 790-795

11 Chen X. A microRNA as a translational repressor of APETALA2 in Arabidopsis flower development. Science 2004; 303: 2022-2025

12 Dostie J, Mourelatos Z, Yang M, Sharma A, Dreyfuss G. Numerous microRNPs in neuronal cells containing novel microRNAs. RNA 2003; 9: 180-186

13 Calin GA, Sevignani C, Dumitru CD, Hyslop T, Noch E, Yendamuri S, Shimizu M, Rattan S, Bullrich F, Negrini M, Croce CM. Human microRNA genes are frequently located at fragile sites and genomic regions involved in cancers. Proc Natl Acad Sci USA 2004; 101: 2999-3004

14 Michael MZ, O' Connor SM, van Holst Pellekaan NG, Young GP, James RJ. Reduced accumulation of specific microRNAs in colorectal neoplasia. Mol Cancer Res 2003; 1: 882-891

15 Metzler M, Wilda M, Busch K, Viehmann S, Borkhardt A. High expression of precursor microRNA-155/BIC RNA in children with Burkitt lymphoma. Genes Chromosomes Cancer 2004; 39: 167-169

16 Meng F, Henson R, Lang M, Wehbe H, Maheshwari S, Mendell JT, Jiang J, Schmittgen TD, Patel T. Involvement of human micro-RNA in growth and response to chemotherapy in human cholangiocarcinoma cell lines. Gastroenterology 2006; 130: 2113-2129

17 Meng F, Wehbe-Janek H, Henson R, Smith H, Patel T. Epigenetic regulation of microRNA-370 by interleukin- 6 in malignant human cholangiocytes. Oncogene 2008; 27: 378-386

18 Mott JL, Kobayashi S, Bronk SF, Gores GJ. mir-29 regulates Mcl-1 protein expression and apoptosis. Oncogene 2007; 26: 6133-6140

19 Bheemanaik S, Reddy YV, Rao DN. Structure, function and mechanism of exocyclic DNA methyltransferases. Biochem 2006; 399: 177-190

20 Nan X, Cross S, Bird A. Gene silencing by methyl-CpGbinding proteins. Novartis Found Symp 1998; 214: 6-16; discussion 16-21, 46-50

21 Esteller M. Cancer epigenomics: DNA methylomes and histone-modification maps. Nat Rev Genet 2007; 8: 286-298

22 Meng F, Henson R, Wehbe-Janek H, Smith H, Ueno Y, Patel T. The MicroRNA let-7a modulates interleukin-6-dependent STAT-3 survival signaling in malignant human cholangiocytes. J Biol Chem 2007; 282: 8256-8264

23 Tannapfel A, Sommerer F, Benicke M, Weinans L, Katalinic A, Geissler F, Uhlmann D, Hauss J, Wittekind C. Genetic and epigenetic alterations of the INK4a-ARF pathway in cholangiocarcinoma. J Pathol 2002; 197: 624-631

24 Tischoff I, Markwarth A, Witzigmann H, Uhlmann D, Hauss J, Mirmohammadsadegh A, Wittekind C, Hengge UR, Tannapfel A. Allele loss and epigenetic inactivation of 3p21.3 in malignant liver tumors. Int J Cancer 2005; 115: 684-689

25 Tischoff I, Wittekind C, Tannapfel A. Role of epigenetic alterations in cholangiocarcinoma. J Hepatobiliary Pancreat Surg 2006; 13: 274-279

26 Yang B, House MG, Guo M, Herman JG, Clark DP. Promoter methylation profiles of tumor suppressor genes in intrahepatic and extrahepatic cholangiocarcinoma. Mod Pathol 2005; 18: 412-420

27 Alpini G, McGill JM, Larusso NF. The pathobiology of biliary epithelia. Hepatology 2002; 35: 1256-1268

28 Sirica AE. Cholangiocarcinoma: molecular targeting strategies for chemoprevention and therapy. Hepatology 2005; 41: 5-15

29 McLean L, Patel T. Racial and ethnic variations in the epidemiology of intrahepatic cholangiocarcinoma in the United States. Liver Int 2006; 26: 1047-1053

30 Harrison SA. New treatments for nonalcoholic fatty liver disease. Curr Gastroenterol Rep 2006; 8: 21-29

31 Møller MB. Molecular control of the cell cycle in cancer: biological and clinical aspects. Dan Med Bull 2003; 50: 118-138 
32 Agrawal A, Yang J, Murphy RF, Agrawal DK. Regulation of the p14ARF-Mdm2-p53 pathway: an overview in breast cancer. Exp Mol Pathol 2006; 81: 115-122

33 Jarnagin WR, Klimstra DS, Hezel M, Gonen M, Fong Y, Roggin K, Cymes K, DeMatteo RP, D'Angelica M, Blumgart LH, Singh B. Differential cell cycle-regulatory protein expression in biliary tract adenocarcinoma: correlation with anatomic site, pathologic variables, and clinical outcome. J Clin Oncol 2006; 24: 1152-1160

34 Lee S, Kim WH, Jung HY, Yang MH, Kang GH. Aberrant $\mathrm{CpG}$ island methylation of multiple genes in intrahepatic cholangiocarcinoma. Am J Pathol 2002; 161: 1015-1022

35 Fleisher AS, Esteller M, Tamura G, Rashid A, Stine OC, Yin J, Zou TT, Abraham JM, Kong D, Nishizuka S, James SP, Wilson KT, Herman JG, Meltzer SJ. Hypermethylation of the hMLH1 gene promoter is associated with microsatellite instability in early human gastric neoplasia. Oncogene 2001; 20: 329-335

36 Koga Y, Kitajima Y, Miyoshi A, Sato K, Kitahara K, Soejima $\mathrm{H}$, Miyazaki K. Tumor progression through epigenetic gene silencing of $\mathrm{O}(6)$-methylguanine-DNA methyltransferase in human biliary tract cancers. Ann Surg Oncol 2005; 12: 354-363

37 Kawanishi S, Hiraku Y, Pinlaor S, Ma N. Oxidative and nitrative DNA damage in animals and patients with inflammatory diseases in relation to inflammation-related carcinogenesis. Biol Chem 2006; 387: 365-372

38 Sugawara H, Yasoshima M, Katayanagi K, Kono N, Watanabe Y, Harada K, Nakanuma Y. Relationship between interleukin-6 and proliferation and differentiation in cholangiocarcinoma. Histopathology 1998; 33: 145-153

39 Yasoshima M, Kono N, Sugawara H, Katayanagi K, Harada K, Nakanuma Y. Increased expression of interleukin-6 and tumor necrosis factor-alpha in pathologic biliary epithelial cells: in situ and culture study. Lab Invest 1998; 78: 89-100

40 Isomoto H, Mott JL, Kobayashi S, Werneburg NW, Bronk
SF, Haan S, Gores GJ. Sustained IL-6/STAT-3 signaling in cholangiocarcinoma cells due to SOCS-3 epigenetic silencing. Gastroenterology 2007; 132: 384-396

41 Hodge DR, Xiao W, Clausen PA, Heidecker G, Szyf M, Farrar WL. Interleukin-6 regulation of the human DNA methyltransferase (HDNMT) gene in human erythroleukemia cells. J Biol Chem 2001; 276: 39508-39511

42 Wehbe H, Henson R, Meng F, Mize-Berge J, Patel T. Interleukin-6 contributes to growth in cholangiocarcinoma cells by aberrant promoter methylation and gene expression. Cancer Res 2006; 66: 10517-10524

43 Scoles DR, Nguyen VD, Qin Y, Sun CX, Morrison H, Gutmann DH, Pulst SM. Neurofibromatosis 2 (NF2) tumor suppressor schwannomin and its interacting protein HRS regulate STAT signaling. Hum Mol Genet 2002; 11: 3179-3189

44 Doki Y, Shiozaki H, Tahara H, Inoue M, Oka H, Iihara K, Kadowaki T, Takeichi M, Mori T. Correlation between E-cadherin expression and invasiveness in vitro in a human esophageal cancer cell line. Cancer Res 1993; 53: 3421-3426

45 Oka H, Shiozaki H, Kobayashi K, Inoue M, Tahara $\mathrm{H}$ Kobayashi T, Takatsuka Y, Matsuyoshi N, Hirano S, Takeichi $\mathrm{M}$. Expression of E-cadherin cell adhesion molecules in human breast cancer tissues and its relationship to metastasis. Cancer Res 1993; 53: 1696-1701

46 Sommers CL, Thompson EW, Torri JA, Kemler R, Gelmann EP, Byers SW. Cell adhesion molecule uvomorulin expression in human breast cancer cell lines: relationship to morphology and invasive capacities. Cell Growth Differ 1991; 2: 365-372

47 Kim BH, Cho NY, Choi M, Lee S, Jang JJ, Kang GH. Methylation profiles of multiple CpG island loci in extrahepatic cholangiocarcinoma versus those of intrahepatic cholangiocarcinomas. Arch Pathol Lab Med 2007; 131: 923-930

48 Endo K, Ashida K, Miyake N, Terada T. E-cadherin gene mutations in human intrahepatic cholangiocarcinoma. J Pathol 2001; 193: 310-317

S- Editor Liu Y L- Editor Roberts SE E- Editor Li HY 